\title{
Co-operation, leadership and learning: Fred Hall and the Co-operative College before 1939
}

\author{
Tom Woodin
}

The Co-operative College, established in 1919, provided a model for other cooperative colleges around the world. In Britain, it was, and remains, a unique organisation with links to a democratic movement of consumer co-operatives (on the wider movement see Gurney 1996; Wilson et al. 2013). For the interwar period, the 'College' was a partial realisation with classes being run out of the Co-operative Union in Manchester, which was the central democratic arena for the movement. The project was led by Fred Hall, adviser of studies at the Union from 1914 (Bellamy and Saville 1972: 145-148). Following the Second World War, the movement purchased Stanford Hall, a country house which became the home of the College until it was sold in the early twenty first century at which time it returned to Manchester. Concentrating upon the early years of the College helps us to understand the complex role of leadership within a working class movement. The work of Hall illustrates opportunities and difficulties of operating with an alternative vision of education for social change.

The College was formed at a time of educational ferment when there was a growing interconnection between the working class movement and the universities. From the late nineteenth century, new universities were developing in major cities while Oxford and Cambridge had nurtured university extension and tutorial classes arranged with the Workers Educational Association (WEA). The co-operative 
movement (or 'co-op') had helped to initiate university extension and hosted extension lectures. Many co-operators were also involved in the WEA, not least its founder, Albert Mansbridge, who had worked for the Co-operative Wholesale Society (CWS). New areas of research and courses of study were developed but, ultimately, the pre-eminence of the Oxbridge system was defended with adult education kept at bay, as 'extra-mural', beyond the walls (Goldman 1995).

The process of change in academic knowledge finds parallels today, most obviously with the idea that contemporary social issues require an interdisciplinary approach. One such area also in need of attention is the history, theory and practice of co-operation which does not easily fit into traditional subject boundaries. Since the 2008 financial crisis and ensuing period of austerity, co-operative ideas and educational initiatives have been re-evaluated. This can be seen in work being done on co-operative higher education (Yeo 2014; Winn 2015a), and most visibly with the mushrooming of co-operative schools of which, by 2016, there were over 800 in existence. These schools have asserted the relevance of co-operative values and principles as an alternative to the current educational framework (Woodin 2015; Woodin forthcoming). Moreover, the present context provides an opportune moment to examine historical examples of higher education and their leadership. Internationally, universities are in a state of flux and have become sites where learning and knowledge are actively contested. In Britain, the division with further education has become blurred as this 'Cinderella' service has been colonised by universities (Wolf 2015: 74). At the same time, commercialism, differentiation and marketization have entrenched wider social divisions into the sector. 


\section{Emergence}

The roots of the co-operative movement stretch back to the early nineteenth century, at a point when liberal economics was spreading its wings. From the 1840s, the consumer co-operative movement witnessed almost uninterrupted growth in terms of both business turnover and membership. By the turn of the century there were just under 1500 independent co-operative societies while membership had grown to three million by 1914 and, on paper, eight million by 1939. The Co-operative College itself would arise out of a broad range of educational activities. For instance, a number of journals were published both nationally and locally by individual societies including the Co-operative News (weekly circulation over 100,000), the Co-operative Educator (circulation around 6,000), and the Wheatsheaf (circulation in the 100s of thousands). Young people were catered for through groups such as the Woodcraft Folk and British Federation of Co-operative Youth as well as publications, story books and junior classes on co-operation. For adults, classes and examinations were held on the history of co-operation, economics of co-operation, industrial history, and more. Employees benefitted from technical and vocational learning (Vernon 2011). In addition, the co-op became an early innovator in correspondence courses for their dispersed membership and, at one point, all courses were available to be studied in this way (Hall 1928: 10). For much of the period, over 50,000 students were enrolled upon Co-operative Union courses each year. Formal classes were complemented with a range of informal educational activities and social events for families, often with entertainers and speakers, were a regular feature of most societies. In addition, the Women's Co-operative Guild was a hive of learning and campaigning on issues such as maternity. 
As this structure was built, co-operators turned to the question of higher education. Ideas for a co-operative college had been simmering for some time and stretched back to the Owenites, such as William Pare. Edward Owen Greening proposed a co-operative university at the 1905 Conference at Stratford while cooperators held meetings with universities and sat on various committees. In 1912-13, Hall and others established the College Herald Circle with the intention to create a college. Their enthusiasm emerged out of various week-end and summer schools that brought together like-minded people in an intellectual and social milieu conducive to the development of co-operative ideas. Summer schools had proved an effective means of harnessing both 'formal instruction' as well as 'informal talks... on the walks, on the picnics, at the dining-table, and in the innumerable talks in the little groups that form...' (Hall 1915: 4). Moreover, the college idea met with sympathy from the wider movement. In 1912, Hall read a paper on the formation of a co-op college and, in 1914, the Union organised a conference on the subject and passed a supportive resolution. Following the War, in 1919, the Co-operative Congress passed two resolutions in favour of a college, requesting that societies contribute to a fund of $£ 50,000$. It was envisaged that the College would serve as an apex organisation for the diverse range of co-operative activity. It would provide leadership and guidance and be 'a crowning piece for our educational edifice' (Hall 1923a: 8)

Such a college would be the headquarters of the educational life of the movement; and its academic and ethical centre. It would give greater vitality to all our class work as well as to the less formal educational work of the Guilds and fellowship branches. We provide elementary classes for juniors; we provide more advanced classes for adults and the Co-operative College is needed to complete the scheme... (Hall 1919: 4). 
It was affirmed that the college was to provide 'a centre for higher education in the specialised subjects required for the full equipment of the co-operator and the further development of efficiency in the Co-operative Movement' (College Herald 1913: 2). Structure, specialisation and 'efficiency', a keyword of the early twentieth century, were evident in co-operative thought as they were in the educational zeitgeist of the time.

There were attempts to make the proposed college a war memorial. During the war the movement had been marginalised by the joint power of the state and capitalist business which was a major reason behind the formation of the Cooperative Party. The Walsall Society resolution to Congress held that 'no worthier memorial of the Peace and of those co-operators who have served and fallen in the war could be established than an institution for the dissemination of the principles of co-operation and harmony in industrial and international relationships' (Walsall Cooperative Society 1919: 46-47; Hall 1918a: 8). Indicative of co-operative thinking, the 'Peace' was capitalised while the 'war' remained in lower case. However, cooperators were also engaged in hard-headed business and the attempt to create an educational memorial was not completely successful. Subsequently, the slump in trade during the 1920s led to the suspension of the appeal for funds (Hall 1928: 6-7). Nevertheless, the College was started by following 'an evolutionary method' with classes at Holyoake House in Manchester while a hostel was acquired which could house up to 40 students (Co-operative Congress 1919: 4).

The perceived need for a college derived from the nature of co-operative education itself which did not fit easily into existing divisions of knowledge. Education was understood in both practical and liberal aspects. The education department of the Rochdale Pioneers had included reading rooms, classes, laboratories and a wide 
range of other educational practices, which would later be characterised as 'a university and technical college combined' (Redfern 1939: 218). The sympathetic commentator and member of the Edmonton Men's Guild, Leonard Woolf, could see the need for both technical and liberal education:

We do not employ engineers in the great C.W.S. factories until we have proof that they have knowledge of engineering; and we cannot do our work within the Co-operative Movement without a real knowledge of politics, economics, and finance, of business structure, of industrial and social problems... there is still more knowledge which is required, if they are to be Co-operative citizens, to enable them to deal intelligently with the wider problems of their class and their nation (Woolf 1914: 2).

In the tradition of adult education, liberal education was seen in practical terms, in relation to the working classes gaining power. Yet the movement also challenged the prevailing dichotomies found in the adult education movement (Harrison 1961; Taylor et al 1985; Woodin 2007). Indeed, the interconnection between the vocational and the humanistic would be a recurring theme and co-operators would claim that technical education could be the basis of the education of the whole person (Woodin 2011). From the inception of the movement, activists pointed to the importance of educating members as a basis for progress. The co-op was a business driven by the impulse to improve people and society. The definition of co-operative education carried a dual conception of internal and external change: 'primarily the formation of co-operative character and opinion, and secondarily, though not necessarily of less import, the training of men and women to take part in industrial and social reforms and municipal life generally' (Hall and Watkins 1937: 168). 
The other significant division within adult education was that between humanistic and political education, the latter supported by the Plebs League and labour colleges which pursued independent education committed to the political aims of the labour movement. These divides also found some parallels in the co-operative movement but, again, they were redefined in co-operative terms. The College was to 'teach men how to apply their knowledge to definite social ends', to create 'a burning desire for social justice, inspire a willingness to work for it, and provide the knowledge how best to attain it' (Hall 1919: 5; also Tawney 1912: 3). For Thomas Anderson, of the York society educational committee, the College was going to provide training and knowledge to challenge the current competitive economic system, and build 'liberty in place of industrial slavery by making us a real democracy' (Anderson 1923: 9). The discussions relating to the formation of a college stimulated new courses that addressed the learning needs of the movement. These included 'co-operation and social problems', 'the welfare of the group' and 'after-war problems', the latter a correspondence course (Hall 1918a: 3). Research organised by the Co-operative Union focused upon co-operative issues and it was hoped the College would take further steps in this direction (Hall 1918a).

\section{Leaders and visions}

Leaders in the co-operative movement worked at the intersection of vision and practical reality. Historically, wide-ranging visions of change had gone hand-in-hand with prosaic, detailed actions in building forms of self-help (Woodin 2011). A spiritual faith in the capacity of working people to create the 'co-operative commonwealth' represented not only a continuation of Owenite themes in the movement, but also 
helped to maintain and motivate loyalty and enthusiasm for the co-op. The confidence in co-operative ideas constituted a secular devotion that drew upon religious traditions. Leaders actively sought new members but, as they arrived in greater numbers, a corresponding concern arose about the danger of diluting the cooperative message. This combined with the fear that elected representatives might themselves be apathetic and that a mutual indifference between these two groups could potentially debilitate the movement. The College was responding to an implicit sense that the movement was falling behind:

Among our leaders there seems to be a lack of confidence in the success of a forward movement and an apprehensiveness about the result. As a result of this over-cautiousness, our advance towards the social ideal is disappointingly slow... we are without a conscious and continuous policy for the redemption of co-operators from the social and economic ills that surround them. It might not be the place of a college to provide such a policy, but it could give us light on some of our problems and direct our attention to fundamentals; and it would put more life and confidence into us if it gave us an increased number of men and women trained in the interpretation of social phenomena (Hall 1919: 9).

At the same time leaders looked askance at the inactivity of many members: 'the apathy of the rank-and-file and their indifference to the fuller objects of the movement are frequently lamented by co-operative leaders' (Hall 1923b: 4).

The College represented an attempt to respond to these challenges. It was to bolster faith with a deeper understanding of facts and principles and instil conviction in the co-operative ideal. In outlining aspects of co-operative education, Hall underlined the necessity to look forwards: 
There must be a vision, or the co-operative movement will perish; cooperators must have imagination, or they will fail; the worker must have confidence in his schemes for social redemption, and must have patience in working them out, or he will always be a victim of the less scrupulous people who look farther ahead (Hall 1923b: 3).

It was claimed that the college would also provide a centre for 'the cultivation of the co-operative spirit' (College Herald 1916: 2) and an avowal of co-operation as a collective force was a necessity:

the common life of the college would do much to develop the feeling of common interests and sympathy between co-operators and to keep alive the idealism which inspired the founders, but which at times seems likely to be swamped (Hall 1919: 4).

In this sense, co-operative education would not be like other educational institutions where the 'principal object is to train students so that they may become more efficient to compete with one another'. Instead, the College was to promote the 'common welfare':

Instead of education for private gain and 'getting on', we stand for education for use and for service. We want education to develop all the potentialities of the individual; but we wish his powers to be used for public good, not for individual aggrandisement. We want education to have a moral purpose as well as an intellectual purpose. We want our students to become not only more intelligent and more clever, but to employ their cleverness for the attainment of desirable ends. (Hall 1918a: 10) 
The injunction applied to the leaders who were answerable to the movement. While paid employees such as Hall tended to be appointed by elected committees, other leaders were directly elected and everyone had to justify their actions and ideas through the accepted democratic channels. The management of the college was itself to 'be vested entirely in the movement, either in the Central Education Committee or in a specially-constituted committee' (Hall 1928: 12).

Moreover, co-operators were infused with the expectation that the movement was to move as a whole. Leaders would be representative of the "best type of members' and this only made sense in an environment where individuals would be limited in their leadership by the intelligence of their co-workers, which may be insufficient to enable the rank-and-file to recognise the merits of good proposals, or insufficient to recognise the capacity and disinterestedness of their leaders. This will cause them to be unwilling to trust and follow these leaders. In any case, the progress of the group will depend upon the intelligence of the mass, and upon the existence, among those who are cooperating, of a group spirit as contrasted with an individualistic spirit. This means that the whole of those who are co-operating must be educated to develop their intelligence and foster the group spirit (Hall 1923b: 4).

The prominence given to higher education was related to the learning of everyone. Education was conceived as a social and economic investment for the common good - an early incarnation of what later become known as the "knowledge economy'. In this vein, the restrictions facing leaders were celebrated by Hall and W. P. Watkins who remarked on the danger for the movement should the business get 
'beyond the understanding of the rank and file, it would get beyond their control' and would rapidly lose its 'democratic character':

In the long run, the direction of the journey is more important than the speed of the journey... the only way of speeding up the co-operative achievement is to quicken the intelligence and increase the co-operative determination of the rank and file (Hall and Watkins 1937: 90).

Marshalling the great body of co-operators behind the vision was indispensable to success. Leaders thus had to tailor their responses not only to the political, economic and social context but also the collective constituencies within the co-operative movement.

Engaging the dispersed individuals committed to co-operative education raised another problem for co-operators. In part, co-operation was to be developed and managed through democratic structures but these comprised a plethora of fragmented autonomous parts. In working through this co-operative labyrinth, Hall and others had to develop a canny sense of strategy in convincing activists of the worthiness of their cause while acting as role-models. Flair and flourish were not enough to bring the College into being. Protracted campaigning work was necessary to amass a threshold of supporters convinced of the value of co-operative education. The College Herald Circle aimed to accomplish its task

by spreading a knowledge of the proposals in the movement (1) by distributing copies of that paper [A Co-operative College]; (2) by securing the reading of the paper at conferences and meetings of the various branches of the Guilds, Students' Fellowship, and A.U.C.E. [Amalgamated Union of Cooperative Employees]; (3) by bringing the proposals to the notice of general 
and educational committees; (4) by articles in the 'Records,' 'Wheatsheafs,' etc,; and (5) in other ways that present themselves (Hall 1919: 13).

This represented hard graft and the active engagement of a significant group of people working on a voluntary basis. With this in mind, Hall implored activists not to shun the 'dry details' of educational organisation. They were often fighting against the 'lack of determination among co-operators to will that "these things shall be"' (Hall 1918b: 7).

However, the Survey Committee, which carried out a review of the movement and published its final report in 1919, fretted about 'a large amount of educational zeal in the movement which has hitherto been insufficiently enlisted for our educational work' and for this reason it was recommended that individuals interested in education were to be brought into membership. All too frequently it was found that these men and women were 'drawn off into other reform movements' (Hall 1918b: appendix; Co-operative Union 1919). The response, paradoxically, was the creation of additional organisational structures, the Co-operator's Educational Fellowship and the College, which it hoped might help to enlist individuals in this cause who would become active propagandists and teachers. Hall aimed to amass a force of 10,000 enthusiasts able to teach and keep alive the spirit of co-operation among the rapidly expanding membership. Co-operative education was nonetheless caught up in a catch 22 situation: the fixed structure of the movement acted as a break upon the development of co-operative spirit and activism but was a problem that could only be addressed through structural innovation which added to the already extensive and intricate machinery. 


\section{Public engagement}

The arguments in favour of a college encompassed not only internal co-operative issues but looked outward to the development of civic democracy. For instance, when speaking at the 1912 Co-operative Congress, the educationist and historian, R. H. Tawney contended that the co-op should act as a catalyst for continuing progress in higher education as it had previously in other areas: 'you have won your way into Elementary, Secondary, and Technical Education, and it is time that you turned your attention to Universities' (Tawney 1912: 12). He wanted an inquiry on educational endowments and urged the movement to take on a 'special responsibility' to act as pioneers in 'removing what is undoubtedly one of the greatest evils in education to-day, the restriction to a privileged few of the opportunities for advanced study which should be open to all' (Tawney 1912: 6).

By contrast, the urge for a distinct identity was a priority for those who argued for 'a self-contained movement, Co-operative Commonwealth, in order to be our own employers, and thus bring about a fairer distribution of wealth...' (Laws 1915: 2). In 1890, Lord Rosebery had described the movement as a 'state within a state', a phrase which captured the imagination of many co-operators. Co-operatives had pioneered new economic and social forms in the nineteenth century such as libraries, reading rooms, scientific education as well as classes on liberal and technical subjects. Each of these social innovations were gradually taken on by the state and represented a growth of educational provision. But there were also drawbacks as the co-operative content of libraries and classes was quietly removed over the passage of time. The neglect of co-operation in mainstream education angered those who argued for the need to keep control of learning and ensure that co-operative knowledge remained relevant to the movement's vision of social 
change. The resulting frustrations nurtured the opinion that alternative examples of higher education had to be constructed by the movement itself. In 1909, W. R. Rae, the chair of the Co-operative Union educational committee, reasoned that the evolving education system might offer benefits to working class children but it was a path with many dangers for the co-operative message:

Too often these travellers, keep too closely to the old road, and imbibe the old prejudices, the old errors. What we want and seek to obtain is a co-operative journey that will end in a co-operative university... So long as the State does not provide it, we must do, as we have in the past, the best we can to provide it ourselves (Rae 1909: 29).

It was a tricky process to navigate because the extension of state activity liberated of funds for direct co-operative purposes but was tied to a declining public influence (Rae 1904; Gurney 1996).

Paradoxically, each step in this direction meant that co-operatives became more isolated from wider streams of activity within the working class movement and in the educational system as a whole. The expansion of public education unavoidably marginalised the movement somewhat. In 1927, Honora Enfield, in an overview of the movement, revealed the contradictory nature of these developments. The concentration upon co-operative education meant that 'those who intend to devote themselves to the Movement' would 'get exactly the training they want' but it had

a tendency to restrict the place given to Co-operation in other educational institutions of the workers' movement, and so to separate Co-operation and its problems from the rest of the Labour movement. 
Enfield advocated a workers' college on the Belgian model which embraced the whole labour movement and allowed for both general and specialist courses. She felt that the strong identity of the British movement could also lead to an element of insularity and lack of direct engagement with universities:

It is curious that in Great Britain co-operation has no recognized place in the public educational system, though Paris and Brussels Universities have their Chairs of Co-operation provided and maintained by Co-operative Societies, and in several countries Co-operation forms a subject in the curriculum of certain types of schools (Enfield 1927: 41).

For instance, the noted co-operator, Louis de Brouckère, held the chair in cooperation at the University of Brussels from 1926-1938 where he lectured widely on the topic (Barbier 1951).

It is possible to identify an oscillation between the desire to impact upon mainstream institutions and the necessity to build up internal co-operative structures. The latter impulse worried about dissipating co-operative identity and this could be evident among outsiders who nevertheless argued for large scale social change. Partly in tune with the position of Enfield, and perhaps contrary to Tawney's ideal of progress, Woolf hoped that the movement might indeed establish a 'working class system of education'. It was something the co-op was eminently well-placed to do:

It is no use imitating the systems of the Universities, the Public Schools, and the Board Schools. These are the old academic systems of the upper and middle classes. Those classes have had their chance. Why should not we show what can be done by a working class system of education, younger, fresher, and more living? The Co-operative Movement provides an 
opportunity such as exists nowhere else in the world. We have the money; we have the skeleton of an organisation; we are not educating with the object of fitting our pupils to earn so many pounds sterling a year; we are not competing with other schools and colleges (Woolf 1914: 5).

It was the very physical presence, achievements and resources of consumer cooperatives that permitted Woolf to dream up such revolutionary ideas about an alternative education system, the beginnings of which could be forged from the considerable materials available to the movement. However, Woolf's educational vision was contained by the hard and fast class barriers of the early twentieth century. He hoped that co-operation 'should enter into the life of men and women completely, changing their view of what the construction of society should be, making them more useful members both of their class and of the State' (Woolf 1914: 1). An apparent acceptance of class divisions could thus go hand in hand with a willingness to countenance fundamental change. It was a predicament shared by cooperative leaders who worked within a system while aiming to transform it.

\section{Limitations}

The dilemmas facing co-operative leaders could not easily be solved and the aspiration for a co-operative commonwealth met with enduring problems. At times the concerns about the conservatism of leaders seemed to be justified by actual results. The limited number of students at the College indicated a lack of progress and this could be waring. In 1939, John Thomas, the new director of education at the Co-operative Union, lamented that the College had only 30 students who were mainly holders of scholarships from individual societies as well as a few private 
students from South Africa, Ceylon, India, Egypt and the USA. Some strongholds of co-operation were hardly represented and he identified a significant imbalance:

Think of the hundreds of thousands that pass through British Universities and Colleges to serve capitalist enterprise. Shall British co-operators with a membership of over eight millions [sic] be content with 20 to 30 students training annually at their College? Not if I can rouse my fellow co-operators to see a new vision of co-operative education! (Thomas 1939: 200, emphasis in original).

His method for stimulating the movement again related to the importance of the vision. With enthusiasm and belief on the part of members, and a realisation of the great potential they held in their hands, change might come. However, the heavy structures of the movement could act as a brake upon concerted action.

Working out coherent programmes on the basis of voluntaristic and democratic action proved problematic. This was compounded by the fact that, on the left, planning and state action were coming to be seen as the major way of addressing social problems. In addition, the formation of the College paralleled debates about a national co-operative society and the 'overlapping' of societies which meant they were competing with each other rather than the wider capitalist world. Local autonomy of individual societies was a cardinal principal that was jealously guarded. Alongside the Co-operative Union, federal co-operative bodies had been built to handle insurance, banking and wholesaling. But in general, the movement remained grounded in its local societies that only reluctantly ceded power to federal organisation after much experimentation. The growing independence of the CWS would be an issue of concern to some societies and may have inhibited the 
development of other federal bodies. This pattern was replicated in relation to education. Some local leaders were wary of the exhortations of those who called for more expenditure on education. Even within societies, education committees were not everywhere in existence and, where they were, some of them laid on minimal provision and were frequently isolated from the central management committees. Common action became much less possible where power and responsibility were so diffused and where funding for formal educational activity remained marginal.

This helps to explain the partial response to the initial proposal for a cooperative college. From one perspective, supportive statements could be made because the central congress and other educational bodies had little power to act upon them. Sympathetic outside commentators had the freedom to express their frustration at the limited achievements given the scale, spread and wealth of the consumer movement. Woolf complained at how little was spent on education (Woolf 1914: 3-4) and Mansbridge also voiced his exasperation at the lack of co-ordination. Resources could not easily be funnelled up the movement in order to develop new ideas. In 1912, he highlighted the 'ridiculous' condition of the Central Education Committee of the Co-operative Union getting by with a grant of $£ 712$ while the rest of the movement devoted over $£ 100,000$ to education (Mansbridge 1912: 490). Although the College was envisioned as a co-ordinating body, it was not to receive a lion's share of the resources during the interwar years.

In addition, the restriction of funds created an environment in which an expectation of overwork became the norm. The co-operator, S. Fairbrother, opined that staff were working ten to twenty hours overtime each week: 'the wages were practically sweating wages... they were sweated from the point of view of overwork, and that could not go on without a deteriorating effect upon the whole work of the 
Educational Department' (Fairbrother 1919: 16). This reflected a wider ambivalence in the co-op about the treatment of its staff who were not immune from the labour struggles found in capitalist enterprises (Gurney 1996). Rather than share profits or power with employees, they were encouraged to join as consumers. T.W. Mercer, hoped that the proposed college might solve grievances that were often the result of misunderstanding; it might equip workers 'for the final struggle between capital privately controlled and labour co-operatively organised...' (Mercer 1916: 2). To some employees, these arguments had a whiff of hypocrisy about them.

Activists promoting the College also grappled with the contested role of women. The Co-operative Women's Guild actively campaigned for women's participation. Many societies had allowed women to become members in their own right. Further, it was planned that the College should do 'something to repair the deficiency' in relation to women's role:

The co-operative movement has been built up by women as well as by men; and educational opportunities for women are as necessary as for men, yet the provision of facilities for the education of women in social science has been notoriously neglected (Hall 1919: 12).

But this concern exposed the continuing marginalisation of women in the movement. Special subjects directed at women, such as 'Women's Place in Society' often assumed fixed and gender differentiated roles (Woodin, 2011). One commentator claimed to have an 'open mind' on the topic of women on educational committees but worried that they would not be able to handle 'rough work' and emphasised difference in order to undermine claims of equality: 
In every great movement - religious, philanthropic - women have been of the greatest service; but still none of us likes the pushing woman, anxious to take the place of men. If women insist upon having all the rights of men, they must necessarily lose the privileges of women. Is this desirable? (Laws 1915: 2)

Similarly, sustaining a belief in the common welfare came under pressure from other social forces. As in broader educational and social developments, difference and differentiation were visible and it was claimed that there would always be leaders who had 'wider vision and greater intelligence' (Hall 1923b: 4 check). Co-operative education had to address the differentiation and hierarchy that pervaded mainstream education. The notion of a 'broad highway' rather than a socially restrictive ladder, championed by the WEA, was actively supported by co-operators. But the position was more difficult to uphold given varying levels of enthusiasm, knowledge and standards. One report on the 1915 summer schools observed a need to recognise prior experience: 'varying grades of students; some students have not previously been class students, and others have been studying systematically for a few years... more differentiation is required' (Summer Schools 1916: 4). The College itself based upon a need for students to pursue a more 'advanced stage' in their studies (Hall 1928: 4) and those with 'low mental power' were expected to benefit from general education (Hall 1923b: 3).

These debates spilled over into the value and meaning of higher forms of education. Various scholarships to Oxford and elsewhere, which were made available for co-operators, following bequests by supporters like E.V. Neale and Thomas Hughes, had proved to be a means of channelling potential students out of the movement. Scholarships and opportunities to study at the College were awarded for a variety of motives which might not be related to the priorities of individual 
societies. On introducing the idea of the college, Hall himself had been quizzed that it might provide a home for the 'sons and daughters of the aristocratic and middle classes of the co-operative movement... the officials, managers, and secretaries of the co-operative movement... the well-to-do members and employees...' (Hornsey 1919: 499). Hall strongly rebutted the claim and argued that everyone would have access to the College. In 1928, he was still at pains to underline that the College was serving the movement; its ex-students were now

managers and secretaries of societies, secretaries of educational committees, organisers and canvassers for societies, members of the staff of national organisations like the Co-operative Union, the Wholesale Society, and the Cooperative Party; whilst others are serving as co-operative journalists and in other capacities, many now acting as teachers of evening classes for local societies. The fear of some critics that the College would educate students who would then leave the Movement has not been justified (Hall 1928: 7).

These activists had become what Antonio Gramsci would later refer to as 'organic intellectuals' (Gramsci 1971). Educating students from around the world was also having an international impact. Yet, it could feel a world away from the life of the average member.

In part, these reservations reflected the fact that the very idea of a 'college' was alien to many in the movement: 'they had the idea that colleges were only for the rich, and that a co-operative college would only be a means of lifting a few students out of their class at the expense of the Co-operative Movement' (Hall 1928: 4). In fact, the 'College' label posed a challenge. In forging plans for a college, there were historical models to draw upon such as the working men's colleges in London, 
Sheffield and elsewhere (Dent 1928). Nevertheless, there was a palpable nervousness about taking on this mantle and an ambiguity about the type of institution that it should become. This became evident over the debates about the ideal, potentially rural, location of the College. As a result, activists were not always completely sure whether their proposals constituted a 'real' college or not. For instance, in 1914, Hall argued that, 'One takes it for granted that the college would be established in some country district, where the work could be carried on under the best conditions.' But he prevaricated on this point and later shifted his position in noting the advantages of working in the heart of the movement:

The presence of the College in Manchester has had certain advantages, such as proximity to the warehouses and many factories of the C.W.S., and contact with the day-by-day life of co-operators and co-operative societies. These advantages are much appreciated by the students, particularly by employeestudents, who are attending the College in order to increase their knowledge of the trade, and the technical subjects bearing upon it (Hall 1928).

Such ambiguities were indicative of the way that the co-op traversed the boundaries and expectations that were being erected in the wider society. After the Second World War, the purchase of a country house in a rural location would in turn eventually come under scrutiny as the costs and purpose of the College were reevaluated in the twenty first century. At each stage, there were gains and losses.

\section{Conclusions}

All leadership must be understood in relation to its social context. The Co-operative College grew out of a long and complex collective history. It came into being to 
address the needs of a democratic consumer movement that had grown to significant proportions. It was to provide a higher education for co-operators which cut across vocational training, liberal learning and education for social change. Although the College was expected to co-ordinate the varied educational activities of the movement, its federated structure, in which power was widely diffused, made it difficult to concentrate resources in the centre. Co-operatives had been built from the ground up and individual societies resisted centralised organisation. Leaders were well aware of the resulting challenges and opportunities. Fred Hall, W. R. Rae and others developed strong visionary thinking to inspire the many societies to provide financial and moral support for a college as well as to build networks of sympathetic teachers and learners. They built upon the everyday experience of co-operators and connected it to comprehensive social change. This was no easy task and was made more difficult in times of economic hardship following World War One. Even though the College was started on a small scale, it nevertheless had to be sustained with a continuing flow of students and income. Additionally, the aspiration to educate for a co-operative commonwealth was frequently frustrated by the reality that the College could only handle relatively small numbers. Yet as leaders strove to build a college of their own, they found themselves at some distance from other labour movement initiatives as well as the rapidly developing mainstream educational system. In arguing for a democratic future, co-operators also had to handle popular ideas about difference and differentiation that were a source of continuing debate.

The implications for understanding higher education leadership today cannot be read off in a simplistic way. Very different assumptions held sway in the interwar years in comparison to the early $21^{\text {st }}$ century. The grounded nature of the movement meant that the College was part of a community of practice. The democratic 
accountability of leaders made them answerable to elected committees. It did have an influence abroad which added to the mix of experiences and internationalist ideas upon which the College was built. Education and learning was to provide the basis for building character for wider service as well as the expansion of a democratic model of business. In doing so, it proved necessary to think beyond the accepted divisions of knowledge. Mainstream forms of liberal education were welcomed but much College work focused upon the future of the movement. While this may have appeared overly specialised to outsiders, co-operative leaders saw it as the route to true equality, justice and democracy. Today, universities contribute to the problem of a democratic deficit in aping for-profit businesses often at the expense of their identities as public institutions. The paucity of vision is reflected in the preoccupation with defending hierarchies, organisational boundaries and market share rather than developing new learning communities as a means for social improvement. As a result, alternative models of co-operative further and higher education may still have a role to play at this present-day historical juncture. 


\section{References}

Barbier, Ch-h (1951) 'A Tribute to Louis de Brouckère - Co-operator', Annals of Collective Economy 32 (2): 113-127.

Bellamy, Joyce M. and Saville, John (1972) Dictionary of Labour Biography, volume 1, Augustus M. Kelley: Clifton, NJ.

College Herald (1916) quotation, 3 (1) May: 2.

Co-operative Congress (1919) 'National Co-operative War Memorial', Co-operative Congress, Manchester: Co-operative Union.

Co-operative Union (1919) General Co-operative Survey, Manchester: Co-operative Union.

Dent, J. J. (1928) Co-operation and the Working Men's College, Manchester: Cooperative Union.

Enfield, A. H. (1927) Co-operation: Its Problems and Possibilities, London: Longmans, Green and Co.

Fairbrother, S. (1919) quoted in Co-operative Congress, Manchester: Co-operative Union.

Goldman, L. (1995) Dons and Workers: Adult Education Since 1850, Oxford: Clarendon.

Gurney, P. (1996) Co-operative Culture and the Politics of Consumption in England 1870-1930, Manchester: Manchester University Press.

Hall, F. (1915) The Summer School for Co-operators, Manchester: Co-operative Union. 
Hall, F. (1918a) Further Prospective Developments of Co-operative Education, Manchester: Co-operative Union.

Hall, F. (1918b), The Work of a Co-operative Educational Association, Manchester: Co-operative Union.

Hall, F. (1919) (fifth ed.) A Co-operative College, Manchester: Co-operative Union.

Hall, F. (1923a) The Necessity for Co-operative Education, Manchester: Cooperative Union.

Hall, F. (1923b) The Co-operator's Educational Fellowship, Manchester: Cooperative Union.

Hall, F. (1928) The Co-operative College and its Work, Manchester: Co-operative Union.

Hall, F. and W.P. Wakins (1937) Co-operation, Manchester: Co-operative Union.

Harrison, J. F. C. (1961) Learning and Living 1790-1960, London: Routledge and Kegan Paul.

Hornsey, H. (1919) quoted in Co-operative Congress, Manchester: Co-operative Union.

Laws, W. H. (1915) The Functions of an Education Committee, Manchester: Cooperative Union North Western Section.

Mansbridge, A. (1912) 'Educational Session at Congress', Co-operative Congress, Manchester: Co-operative Union: 485-490.

Mercer, T.W. (1919) 'Co-operative Employés and the Co-operative College', College Herald 3 (1): 2-3. 
Rae, W. R. (1904) How Best can Co-operative Societies Utilise their Educational Funds in View of the Educational Facilities now Provided by Municipal and Local Authorities, Manchester: Co-operative Union.

Rae, W. R. (1909) 'Inaugural Address', Co-operative Congress, Manchester: Cooperative Union, 20-35.

Redfern, P. (1939) 'Education Past and Present', Co-operative Review 13 (7) July: 218-220.

Summer Schools (1916) 'Official Report of Co-operative Summer Schools, 1915', College Herald, 3 (1): 4.

Tawney, R. H. (1912) Education and Social Progress, Manchester: Co-operative Union.

Taylor, R., Rockhill, K. and Fieldhouse, R. (1985) University Adult Education in England and the USA, London: Croom Helm.

Thomas, J. (1939) ‘Education Outlook’, Co-operative Review 13 (7): 198-201.

Vernon, K. (2011) 'Values and Vocation: Educating the Co-operative Workforce, 1918-1939, in A. Webster, A. Brown, D. Stewart, J.K. Walton and L. Shaw (eds) The Hidden Alternative: Co-operative Values, Past, Present and Future, 37-58, Manchester: Manchester University Press.

Walsall Co-operative Society (1919) 'Resolution', in Co-operative Congress Report, ed A. Whitehead, Manchester: Co-operative Union.

Wilson, J. F., Webster, A. and Vorberg-Rugh, R. (2013) Building Co-operation: A Business History of the Co-oprative Group, 1863-2013, Oxford: Oxford University Press. 
Winn, J. (2015) 'The Co-operative University: Labour, Property and Pedagogy', Power and Education, 7 (1): 39-55.

Wolf, A. (2015) Heading for the Precipice: Can Further and Higher Education Funding Policies be Sustained? London: Policy Institute, King's College.

Woodin, T. (in press) 'Co-operative Education, History and Neoliberalism - the Dilemmas of Building Alternatives', in Alternative Visions, Systems, Discourse and Professional Practice: Resisting Neo Liberal Education, eds. T. Rudd and I. F. Goodson. Dordrecht: Sense.

Woodin, T. (2014) ed. Co-operation, Learning and Co-operative Values. London: Routledge.

Woodin, T. and Fielding, M. (2013) eds. Special issue of Forum, 55, 2.

Woodin, T. (2013) Tom Woodin and Michael Fielding, 'Co-operative Education for a New Age? Special issue of Forum,' 55, 2, 179-184.

Woodin, T. (2012) 'Co-operative schools: building communities in the twenty first century', Forum, 54, 2, 327-339.

Woodin, T. (2007) 'Working Class Education and Social Change in Nineteenth and Twentieth Century Britain', History of Education 36 (4/5): 483-496.

Woolf, L. (1914) Education and the Co-operative Movement, London: Women's Cooperative Guild.

Yeo, S. (2014) 'The Co-operative University: Transforming Higher Education,' in T. Woodin, ed., Co-operation, Learning and Co-operative Values, London: Routledge. 